\title{
Pengaruh Frekuensi Pemberian Pupuk Organik Cair dan Takaran Biochar terhadap Pertumbuhan dan Hasil Sawi Pakcoy (Brassica rappa L.)
}

\author{
Asep Iksan Gumelar ${ }^{a}$ dan Yunus Kornelis $\mathrm{To}^{\mathrm{b}}$ \\ ${ }^{a}$ Fakultas Pertanian, Universitas Timor, Kefamenanu, TTU - NTT, Indonesia, email: gumelar.ikhsan@unimor.ac.id
}

${ }^{a}$ Fakultas Pertanian, Universitas Timor, Kefamenanu,TTU - NTT, Indonesia, email: toyunus26@gmail.com

\section{Article Info}

Article history:

Received 27 November 2020

Received in revised form 7 Januari 2021 Accepted 15 Januari 2021

DOI:

https://doi.org/10.32938/sc.v6i01.1227

\section{Keywords:}

Brasicca rappa $L$

Frekuensi

Pupuk organik cair

Takaran biochar

\section{Abstrak}

Penelitian ini bertujuan untuk mengetahui pengaruh frekuensi pemberian pupuk organik cair dan biochar terhadap pertumbuhan dan hasil tanaman Pakcoy danuntukmendapatkan frekuensi pemberian pupuk cair yang tepat untuk pertumbuhan dan hasil tanaman pakcoy.Penelitian ini telahdilaksanakan selama satu kali musim tanam dari bulan Agustus sampai September 2020, di lahan kebun Bapak Marten Kaet yang berlokasi di Kelurahan Benpasi, Kecamatan Kota Kefamenanu, Kabupaten Timor Tengah Utara (TTU), Provinsi Nusa Tenggara Timur (NTT). Penelitian ini menggunakan Rancangan Acak Kelompok (RAK) 2 Faktorial yaitu: Faktor pertama: biochar yang terdiri dari 3 taraf, yaitu: biochar $10 \mathrm{t} / \mathrm{ha}$, biochar $20 \mathrm{t} / \mathrm{ha}$, biochar $30 \mathrm{t} / \mathrm{ha}$. Faktor kedua adalah frekuensi penyiraman pupuk cair yang terdiri dari 4 taraf perlakuan, yaitu: $5 \mathrm{ml} /$ liter air: 2 kali seminggu, $5 \mathrm{ml} /$ liter air: $1 \mathrm{kali}$ seminggu, $10 \mathrm{ml} /$ liter air: $2 \mathrm{kali}$ seminggu, 10 $\mathrm{ml} /$ liter air: 1 kali seminggu.Sehingga terdapat 12 kombinasi perlakuan, yaitu: $\mathrm{B}_{1} \mathrm{~F}_{1}, \mathrm{~B}_{1} \mathrm{~F}_{2}, \mathrm{~B}_{1} \mathrm{~F}_{3}, \mathrm{~B}_{1} \mathrm{~F}_{4}, \mathrm{~B}_{2} \mathrm{~F}_{1}, \mathrm{~B}_{2} \mathrm{~F}_{2}, \mathrm{~B}_{2} \mathrm{~F}_{3}, \mathrm{~B}_{2} \mathrm{~F}_{4}, \mathrm{~B}_{3} \mathrm{~F}_{1}$, $\mathrm{B}_{3} \mathrm{~F}_{2}, \mathrm{~B}_{3} \mathrm{~F}_{3}, \mathrm{~B}_{3} \mathrm{~F}_{4}$ yang diulang sebanyak 3 kali sehingga terdapat 36satuan unit percobaan. Hasil penelitian menunjukkan bahwa tidak terjadi interaksi serta beda nyata antara perlakuan takaran biochar dan frekuensi penyiraman POC terhadap pertumbuhan dan hasi tanaman sawi (Brassica rappa L.). Namun terjadi beda nyata pada parameter luas daun. Pada perlakuan takaran biochar $30 \mathrm{t} / \mathrm{ha}$ dan frekuensi penyiraman POC 5 ml/L mampu meningkatkan pertumbuhan serta hasil tanaman Sawi Pakcoy (Brassica rappa L.)

\section{Pendahuluan}

Lahan kering iklim kering secara umum didefinisikan sebagai suatu hamparan lahan yang tidak pernah digenangi atau tergenang air pada sebagian besar waktu dalam setahun, dengan curah hujan $<2.000 \mathrm{~mm} / \mathrm{tahun} \mathrm{dan}$ mempunyai bulan kering $>7$ bulan $(<100 \mathrm{~mm} / \mathrm{bulan})$ (Mulyani dan Sarwan 2013). Berdasarkan hasil penelitian, jenis tanah di NTT dan NTB berasal dari berbagai bahan induk yaitu aluvium, batu kapur, batu karang, sedimen, sedimen kapur, dan volkanik, yang menurunkan lima ordo tanah yaitu Inceptisols,Alfisols, Vertisols, Mollisols, dan Entisols. Masing-masing ordo menurunkan 3-4 subgrup tanah (Balitklimat, 2003). Konsumsi sayur propors penduduk Indonesia $\geq 10$ tahun sebesar $93.5 \%$. Namun konsumsi buah dan sayur di Indonesia pada tahun 2016 kurang dari setengah, konsumsi yang direkomendasikan WHO, sebagian besar penduduk Indonesia mengkonsums buah dan sayur sebanyak 173 gram per hari, lebih kecil dari Angka Kecukupan Gizi (AKG) yang direkomendasikan yaitu sebesar 400 gram perkapita per hari (BMKG, 2017).

Sayuran sangat penting dikonsumsi untuk kesehatan masyarakat karena nilai gizi yang terkandung dalam sayur-sayuran sangat tinggi. Salah satu jenis sayuran yang banyak dibudidayakan di Indonesia adalah pakcoy. Sawi pakcoy (Brassica rappa L.) merupakan salah satu tanaman dari keluarga Cruciferae yang sangat diminati karena mengandung protein, mineral, lemak, karbohidrat, $\mathrm{Ca}, \mathrm{P}, \mathrm{Fe}$, vitamin A, B, C, E, K, A, B, B2 dan B6,yang sangat baik untuk kesehatan. Selain itu pakcoy memiliki manfaat untuk mencegah kanker, hipertensi, dan penyakit jantung sehingga membantu kesehatan pada sistem pencernaan dan mencegah anemia bagi ibu hamil (Tania et al., 2012). Permintaan dan kebutuhan sawi pakcoy terus meningkat sesuai dengan pertambahan jumlah penduduk. Namun, produksi sawi pakcoy masih mengalami fluktuasi pada tahun $2015: 600,188$ t/ha, $2016: 601,198 \mathrm{t} / \mathrm{ha}$ 2017: 627,598 t/ha, 2018: 635,982 t/ha, 2019: 652,723 t/ha (Badan Pusat Statistik dan Direktorat Jenderal Hortikultura, 2019). Hal tersebut disebabkan oleh rendahnya tingkat kesuburan tanah dan daya ikat air dalam tanan yang semakin menurun karena kekurangan bahan organik dan unsur hara sehingga menurunkan hasil produksi tanaman sawi pakcoy. Untuk mengatasi masalah tersebut maka perlu adanya upaya pengembangan teknologi dalam membudidayakan tanaman sawi pakcoy. Salah satu upaya yang perlu dilakukan yaitu melalui penambahan bahan organik tanah berupa biochar dan pupuk organik cair (POC).

Biochar merupakan arang hayati yang berasal dari pembakaran tidak sempurna (pirolisis) bahan organik sisa-sisa hasil pertanian yang dapa meningkatkan kualitas tanah dan dapat digunakan sebagai salah satu alternatif untuk pengelolaan tanah (Gani, 2009). Dalam proses pembuatannya, sekita $50 \%$ dari karbon yang ada dalam bahan dasar terkandung dalam biochar, dekomposisi biologi biasanya kurang dari 20\% setelah 5-10 tahun, sedangkan pada pembakaran hanya $3 \%$ karbon yang tertinggal, biochar juga dapat menyimpan karbon secara stabil selama ribuan tahun dengan cara membenamkan ke dalam tanah (Gani, 2009).Pemanfaatan biochar sebagai bahan pembenah (amelioran) tanah telah lama dilakukan. Sebagai contoh, "Terra Preta de Indio" di Amazon Basin yang terbentuk karena aktivitas perladangan berpindah. Tanah ini kaya residu organik yang berasal dari pembakaran biomassa kayu hutan. Tanah "Terra Preta de Indio" mengandung karbon $(\mathrm{C})$, nitrogen $(\mathrm{N})$, kalsium $(\mathrm{Ca})$, fosfor $(\mathrm{P})$, tembaga $(\mathrm{Zn})$, dan mangan (Mn) yang lebih tinggi daripada jenis tanah lainnya. Tanah ini dikelompokan dalam jenis Latosol (Glaser et al., 2001; Sombroek et al., 2003)

Pupuk organik merupakan salah satu jenis pupuk yang ramah lingkungan karena mengandung bahan-bahan penting yang dibutuhkan untuk memperbaik tingkat kesuburan tanah baik fisik, kimia dan biologi. Pupuk organik juga dapat berfungsi sebagai pemantap agregat tanah disamping sebagai sumber hara penting bagi tanah dan tanaman. Penggunaan pupuk organik dalam jangka panjang dapat meningkatkan produktivitas lahan dan dapat mencegah degradasi lahan sehingga penggunaannya dapat membantu upaya konservasi tanah yang lebih baik (Musnamar, 2003). Berdasarkan bentuknya pupuk organik terbagi menjadi dua yaitu pupuk organik padat dan pupuk orgnaik cair. Penelitian ini menggunakan pupuk organik cair karena dapat memperbaiki sifat fisik, kimia, dan biologi tanah, juga membantu meningkatkan produksi tanaman, meningkatkan kualitas produk tanaman, mengurangi penggunaan pupuk anorganik dan sebagai alternatif pengganti pupuk kandang (Parman, 2007). Penggunaan pupuk organik cair dapat meningkatkan unsur nitrogen di dalam tanah, karena pupuk cair lebih mudah diserap oleh tanaman karena unsur-unsur di dalamnya sudah terurai. Kelebihan dari pupuk cair adalah kandungan haranya bervariasi yaitu mengandung hara makro dan mikro, penyerapan haranya berjalan lebih cepat karena sudah terlarut (Hadisuwito, 2007). Pupuk organik cair unsur haranya lebih cepat tersedia dan mudah diserap akar tanaman. Selain dengan cara disiramkan pupuk cair dapat digunakan langsung dengan cara disemprotkan pada daun atau batang tanaman (Pardosi, et al., 2014). Namun kelemahan dari pupuk organik pada umumnya adalah kandungan unsur haranya sangat rendah dan lambat tersedia bagi tanaman (Jusuf, 2006)

\section{Metode}

Penelitian dilaksanakan selama satu kali musim tanam dari bulan Agustus sampai September 2020, di Lahan Bapak Marten Kaet yang berlokasi di Kelurahan Benpasi, Kecamatan Kota Kefamenanu, Kabupaten Timor Tengah Utara (TTU), Provinsi Nusa Tenggara Timur (NTT). Penelitian ini dilakukan dengan menggunakan Rancangan Acak Kelompok (RAK) 2 Faktorial yaitu: Faktor pertama: Biochar yang disimbolkan dengan (B) yang terdiri dari 3 taraf, yaitu: $\mathrm{B}_{1}=$ biochar 10 ton/ha, $\mathrm{B}_{2}=$ biochar 20 ton/ha, $\mathrm{B}_{3}=$ biochar 30 ton $/ \mathrm{ha}$. Faktor kedua adalah frekuensi penyiraman pupuk cair yang disimbolkan dengan $(F)$ yang terdiri dari 4 taraf perlakuan, yaitu: $F_{1}=5 \mathrm{ml} /$ liter air: $2 \mathrm{kali}$ seminggu, $F_{2}=5 \mathrm{ml} /$ liter air: 1 kali seminggu, $F_{3}=10 \mathrm{ml} /$ liter air: $2 \mathrm{kali}$ seminggu, $F_{4}=10 \mathrm{ml} /$ liter air: $1 \mathrm{kali}$ seminggu.Sehingga terdapat $12 \mathrm{kombinasi}$ perlakuan, yaitu: $\mathrm{B}_{1} \mathrm{~F}_{1}, \mathrm{~B}_{1} \mathrm{~F}_{2}, \mathrm{~B}_{1} \mathrm{~F}_{3}, \mathrm{~B}_{1} \mathrm{~F}_{4}, \mathrm{~B}_{2} \mathrm{~F}_{1}, \mathrm{~B}_{2} \mathrm{~F}_{2}, \mathrm{~B}_{2} \mathrm{~F}_{3}, \mathrm{~B}_{2} \mathrm{~F}_{4}, \mathrm{~B}_{3} \mathrm{~F}_{1}, \mathrm{~B}_{3} \mathrm{~F}_{2}$, $\mathrm{B}_{3} \mathrm{~F}_{3}, \mathrm{~B}_{3} \mathrm{~F}_{4}$ yang diulang sebanyak 3 kali sehingga terdapat 36 satuan unit percobaan. Parameter percobaan ini terdiri dari parameter lingkungan Suhu tanah, derajat keasaman tanah, daya hantar listrik, kadar lengas tanah, berat volume tanah, serta parameter pertumbuhan dan hasil diantaranya tinggi tanaman, jumlah daun, panjang akar, berat segar total, berat segar ekonomi, berat segar non ekonomi, index panen, dan luas daun.Data dianalisis dengan menggunakan sidik ragam (Anova) Rancangan Acak Kelompok (RAK). Ratarata perlakuan selanjutnya diuji lanjut dengan menggunakan Duncan Multipel Range Test (DMRT) dengan petunjuk Gomez dan Gomez (1995). Analisis data menggunakan program SAS 9.1.

\section{Hasil dan Pembahasan \\ 3.1 Hasil Suhu Tanah}

Hasil sidik ragam anova menunjukkan tidak terjadi interaksi antara perlakuan takaran biochar dan frekuensi penyiraman pupuk organik cair terhadap parameter suhu tanah. Pada perlakuan takaran biochar 30 t/ha memberikan nilai suhu tanah terendah pada awal pengamatan namun pada akhir pengamatan takaran biochar 10 t/ha memberikan nilai suhu tanah terendah dan tidak berbeda nyata. Sedangkan pada perlakuan frekuensi 
penyiraman $5 \mathrm{ml} / \mathrm{L}$ 1x seminggu memberikan nilai terendah pada awal pengamatan namun pada akhir pengamatan perlakuan frekuensi penyiraman 5 $\mathrm{ml} / \mathrm{L} 2 \mathrm{x}$ seminggu memberikan nilai suhu tanah terendah meskipun tidak berbeda nyata (Tabel 1).

Tabel 1. Suhu Tanah

\begin{tabular}{|c|c|c|c|c|c|c|}
\hline \multirow{2}{*}{$\begin{array}{c}\text { Waktu } \\
\text { Pengamatan }\end{array}$} & \multirow{2}{*}{$\begin{array}{l}\text { Takaran } \\
\text { Biochar }\end{array}$} & \multicolumn{4}{|c|}{ Frekuensi Penyiraman POC } & \multirow[b]{2}{*}{ Rerata } \\
\hline & & $\begin{array}{l}5 \mathrm{Ml} / \mathrm{L} 2 \mathrm{x} \\
\text { Seminggu }\end{array}$ & $\begin{array}{l}5 \mathrm{Ml} / \mathrm{L} 1 \mathrm{x} \\
\text { Seminggu }\end{array}$ & $\begin{array}{l}10 \mathrm{Ml} / \mathrm{L} 2 \mathrm{x} \\
\text { Seminggu }\end{array}$ & $\begin{array}{c}10 \mathrm{Ml} / \mathrm{L} 1 \mathrm{x} \\
\text { Seminggu }\end{array}$ & \\
\hline \multirow{4}{*}{$\begin{array}{c}\text { Suhu Tanah } \\
\text { Awal }\end{array}$} & $10 \mathrm{~T} / \mathrm{Ha}$ & 26.00 & 25.33 & 25.67 & 26.00 & $25.75 \mathrm{a}$ \\
\hline & $20 \mathrm{~T} / \mathrm{Ha}$ & 26.00 & 25.67 & 25.33 & 27.00 & $26.00 \mathrm{a}$ \\
\hline & $30 \mathrm{~T} / \mathrm{Ha}$ & 25.33 & 25.00 & 26.00 & 25.33 & $25.42 \mathrm{a}$ \\
\hline & Rerata & $25.78 \mathrm{a}$ & $25.33 a$ & $25.67 \mathrm{a}$ & $26.11 \mathrm{a}$ & $(-)$ \\
\hline \multirow{4}{*}{$\begin{array}{c}\text { Suhu Tanah } \\
\text { Akhir }\end{array}$} & $10 \mathrm{~T} / \mathrm{Ha}$ & 26.67 & 28.00 & 26.67 & 26.33 & $26.92 a$ \\
\hline & $20 \mathrm{~T} / \mathrm{Ha}$ & 27.33 & 28.67 & 28.00 & 29.00 & $28.25 \mathrm{a}$ \\
\hline & $30 \mathrm{~T} / \mathrm{Ha}$ & 27.67 & 28.67 & 28.00 & 28.00 & $28.08 \mathrm{a}$ \\
\hline & Rerata & $27.22 \mathrm{a}$ & $28.44 \mathrm{a}$ & $27.56 \mathrm{a}$ & $27.78 \mathrm{a}$ & $(-)$ \\
\hline
\end{tabular}

Keterangan: Angka pada baris dan kolom diikuti huruf yang sama menunjukan beda pada tingkat nyata ( $\alpha$ ) 0,05 menurut uji DMRT, (-) tidak terjadi interaksi antar faktor

\section{Derajat Keasaman Tanah}

Hasil sidik ragam anova menunjukkan tidak terjadi interaksi antara perlakuan takaran biochar dan frekuensi penyiraman pupuk organik cair terhadap parameter dearajat keasaman tanah $(\mathrm{pH})$. Pada perlakuan takaran biochar $20 \mathrm{t} / \mathrm{ha}$ dan $30 \mathrm{t} / \mathrm{ha}$ memberikan nilai derajat keasaman tanah tertinggi pada awal pengamatan namun pada akhir pengamatan takaran biochar $30 \mathrm{t} / \mathrm{Ha}$ memberikan nilai derajat keasaman tanah tertinggi dan tidak berbeda nyata. Sedangkan pada perlakuan frekuensi penyiraman $5 \mathrm{ml} / \mathrm{L} 2 \mathrm{x}$ seminggu memberikan nilai terendah pada awal dan berbeda nyata dengan perlakuan lainnya sedangkan perlakuan yang lainnya memberikan nilai yang sama yaitu pH 6,29 namun pada akhir pengamatan perlakuan frekuensi penyiraman 10 $\mathrm{ml} / \mathrm{L} 2 \mathrm{x}$ seminggu memberikan nilai derajat keasaman tanah tertinggi meskipun tidak berbeda nyata (Tabel 2)

Tabel 2. Derajat Keasaman Tanah

\begin{tabular}{|c|c|c|c|c|c|c|}
\hline \multirow[b]{2}{*}{$\begin{array}{c}\text { Waktu } \\
\text { Pengamatan }\end{array}$} & \multirow[b]{2}{*}{$\begin{array}{l}\text { Takaran } \\
\text { Biochar }\end{array}$} & \multicolumn{4}{|c|}{ Frekuensi penyiraman POC } & \multirow[b]{2}{*}{ Rerata } \\
\hline & & $\begin{array}{c}5 \mathrm{ml} / \mathrm{L} \\
2 \mathrm{x} \\
\text { seminggu }\end{array}$ & $\begin{array}{c}5 \mathrm{ml} / \mathrm{L} \\
1 \mathrm{x} \\
\text { seminggu }\end{array}$ & $\begin{array}{c}10 \mathrm{ml} / \mathrm{L} \\
2 \mathrm{x} \\
\text { seminggu }\end{array}$ & $\begin{array}{c}10 \mathrm{ml} / \mathrm{L} \\
1 \mathrm{x} \\
\text { seminggu }\end{array}$ & \\
\hline \multirow{4}{*}{ Awal } & $10 \mathrm{t} / \mathrm{Ha}$ & 6.25 & 6.24 & 6.27 & 6.33 & $6.27 \mathrm{a}$ \\
\hline & $20 \mathrm{t} / \mathrm{Ha}$ & 6.20 & 6.33 & 6.31 & 6.26 & $6.28 \mathrm{a}$ \\
\hline & $30 \mathrm{t} / \mathrm{Ha}$ & 6.26 & 6.30 & 6.28 & 6.29 & $6.28 \mathrm{a}$ \\
\hline & Rerata & $6.24 b$ & $6.29 a$ & $6.29 a$ & $6.29 a$ & $(-)$ \\
\hline \multirow{4}{*}{ Akhir } & $10 \mathrm{t} / \mathrm{Ha}$ & 6.25 & 6.29 & 6.29 & 6.24 & $6.27 \mathrm{a}$ \\
\hline & $20 \mathrm{t} / \mathrm{Ha}$ & 6.28 & 6.23 & 6.26 & 6.25 & $6.25 \mathrm{a}$ \\
\hline & $30 \mathrm{t} / \mathrm{Ha}$ & 6.25 & 6.29 & 6.28 & 6.30 & $6.28 \mathrm{a}$ \\
\hline & Rerata & $6.26 \mathrm{a}$ & $6.27 \mathrm{a}$ & $6.28 \mathrm{a}$ & $6.26 a$ & $(-)$ \\
\hline
\end{tabular}

Keterangan: Angka pada baris dan kolom diikuti huruf yang sama menunjukan beda pada tingkat nyata $(\alpha)$ 0,05menurut uji DMRT, (-) tidak terjadi interaksi antar faktor

\section{Daya Hantar Listrik Tanah}

Hasil sidik ragam anova menunjukkan tidak terjadi interaksi $(\mathrm{P}>0.05)$ antara perlakuan takaran biochar dan frekuensi penyiraman pupuk organik cair terhadap parameter daya hantar listrik tanah. Pada perlakuan takaran biochar 30 t/ha memberikan nilai daya hantar listrik tanah tertinggi pada awal maupun akhir pengamatan dan tidak berbeda nyata. Sedangkan pada perlakuan frekuensi penyiraman $5 \mathrm{ml} / \mathrm{L} 2 \mathrm{x}$ seminggu memberikan nilai tertinggi pada awal maupun akhir pengamatan meskipun tidak berbeda nyata (Tabel 3).

$\underline{\text { Tabel 3. Daya Hantar Listrik }}$

\begin{tabular}{ccccccc}
\hline \multirow{3}{*}{$\begin{array}{c}\text { Waktu } \\
\text { Pengamatan }\end{array}$} & Takaran & $5 \mathrm{ml} / \mathrm{L}$ & $5 \mathrm{ml} / \mathrm{L}$ & $10 \mathrm{ml} / \mathrm{L}$ & $10 \mathrm{ml} / \mathrm{L}$ & \multirow{2}{*}{ Rerata } \\
\cline { 3 - 6 } & Biochar & $2 \mathrm{x}$ & $1 \mathrm{x}$ & $2 \mathrm{x}$ & $1 \mathrm{x}$ & \\
& & seminggu & seminggu & seminggu & seminggu & \\
\hline \multirow{5}{*}{ Awal } & $10 \mathrm{t} / \mathrm{Ha}$ & 141.00 & 151.00 & 135.33 & 134.67 & $140.50 \mathrm{a}$ \\
& $20 \mathrm{t} / \mathrm{Ha}$ & 153.67 & 147.33 & 141.33 & 140.33 & $145.67 \mathrm{a}$ \\
& $30 \mathrm{t} / \mathrm{Ha}$ & 151.00 & 142.33 & 156.00 & 150.67 & $150.00 \mathrm{a}$ \\
\cline { 2 - 6 } & Rerata & $148.56 \mathrm{a}$ & $146.89 \mathrm{a}$ & $144.22 \mathrm{a}$ & $141.89 \mathrm{a}$ & $(-)$ \\
\hline \multirow{4}{*}{ Akhir } & $10 \mathrm{t} / \mathrm{Ha}$ & 145.00 & 152.00 & 136.67 & 136.00 & $142.42 \mathrm{a}$ \\
& $20 \mathrm{t} / \mathrm{Ha}$ & 155.33 & 149.33 & 141.33 & 141.00 & $146.75 \mathrm{a}$ \\
& $30 \mathrm{t} / \mathrm{Ha}$ & 152.33 & 137.67 & 156.33 & 145.00 & $147.83 \mathrm{a}$ \\
\cline { 2 - 6 } & Rerata & $150.89 \mathrm{a}$ & $146.33 \mathrm{a}$ & $144.78 \mathrm{a}$ & $140.67 \mathrm{a}$ & $(-)$ \\
\hline
\end{tabular}

Keterangan: Angka pada baris dan kolom diikuti huruf yang sama menunjukan beda pada tingkat nyata ( $\alpha$ ) 0,05menurut uji DMRT, (-) tidak terjadi interaksi antar faktor

\section{Kadar Lengas Tanah}

Hasil sidik ragam anova menunjukkan tidak terjadi interaksi antara perlakuan takaran biochar dan frekuensi penyiraman pupuk organik cair terhadap parameter kadar lengas tanah. Pada perlakuan takaran biochar $10 \mathrm{t} / \mathrm{ha}$ memberikan nilai kadar lengas tanah tertinggi pada awal pengamatan maupun akhir pengamatan dan tidak berbeda nyata. Sedangkan pada perlakuan frekuensi penyiraman $10 \mathrm{ml} / \mathrm{L} 1 \mathrm{x}$ seminggu memberikan nilai tertinggi pada awal maupun akhir pengamatan meskipun tidak berbeda nyata (Tabel 4)

$\underline{\text { Tabel 4. Kadar Lengas Tanah }}$

\begin{tabular}{|c|c|c|c|c|c|c|}
\hline \multirow[b]{2}{*}{$\begin{array}{c}\text { Waktu } \\
\text { Pengamatan }\end{array}$} & \multirow[b]{2}{*}{$\begin{array}{l}\text { Takaran } \\
\text { Biochar }\end{array}$} & \multicolumn{4}{|c|}{ Frekuensi penyiraman POC } & \multirow[b]{2}{*}{ Rerata } \\
\hline & & $\begin{array}{c}5 \mathrm{ml} / \mathrm{L} \\
2 \mathrm{x} \\
\text { seminggu }\end{array}$ & $\begin{array}{c}5 \mathrm{ml} / \mathrm{L} \\
1 \mathrm{x} \\
\text { seminggu }\end{array}$ & $\begin{array}{c}10 \mathrm{ml} / \mathrm{L} \\
2 \mathrm{x} \\
\text { seminggu }\end{array}$ & $\begin{array}{c}10 \mathrm{ml} / \mathrm{L} \\
1 \mathrm{x} \\
\text { seminggu }\end{array}$ & \\
\hline \multirow{4}{*}{ Awal } & $10 \mathrm{t} / \mathrm{Ha}$ & 11.43 & 15.97 & 16.43 & 15.22 & $14.76 \mathrm{a}$ \\
\hline & $20 \mathrm{t} / \mathrm{Ha}$ & 14.37 & 10.60 & 14.35 & 16.59 & $13.98 \mathrm{a}$ \\
\hline & $30 \mathrm{t} / \mathrm{Ha}$ & 14.65 & 14.89 & 13.01 & 13.39 & $13.99 \mathrm{a}$ \\
\hline & Rerata & $13.48 \mathrm{a}$ & $13.82 \mathrm{a}$ & $14.60 \mathrm{a}$ & $15.07 \mathrm{a}$ & $(-)$ \\
\hline \multirow{4}{*}{ Akhir } & $10 \mathrm{t} / \mathrm{Ha}$ & 11.39 & 16.00 & 17.53 & 15.21 & $15.03 \mathrm{a}$ \\
\hline & $20 \mathrm{t} / \mathrm{Ha}$ & 14.36 & 10.89 & 14.31 & 16.56 & $14.03 \mathrm{a}$ \\
\hline & $30 \mathrm{t} / \mathrm{Ha}$ & 14.60 & 14.86 & 13.02 & 13.38 & $13.96 \mathrm{a}$ \\
\hline & Rerata & $13.45 \mathrm{a}$ & $13.92 \mathrm{a}$ & $14.95 \mathrm{a}$ & $15.05 \mathrm{a}$ & $(-)$ \\
\hline
\end{tabular}

Keterangan: Angka pada baris dan kolom diikuti huruf yang sama menunjukan beda pada tingkat nyata ( $\alpha$ ) 0,05 menurut uji DMRT, (-) tidak terjadi interaksi antar faktor

\section{Berat Volume Tanah}

Hasil sidik ragam anova menunjukkan tidak terjadi interaksi antara perlakuan takaran biochar dan frekuensi penyiraman pupuk organik cair terhadap parameter berat volume tanah. Pada perlakuan takaran biochar $30 \mathrm{t} / \mathrm{ha}$ memberikan nilai berat volume tanah tertinggi pada awal pengamatan namun pada akhir pengamatan takaran biochar $10 \mathrm{~T} / \mathrm{ha}$ memberikan nilai berat volume tanah tertinggi dan tidak berbeda nyata. Sedangkan pada perlakuan frekuensi penyiraman $5 \mathrm{ml} / \mathrm{L} 2 \mathrm{x}$ seminggu memberikan nilai tertinggi pada awal pengamatan dan berbeda nyata dengan perlakuan lainnya sedangkan pada akhir pengamatan perlakuan frekuensi penyiraman $10 \mathrm{ml} / \mathrm{L} \quad 1 \mathrm{x}$ seminggu memberikan nilai berat volume tanahtertinggi meskipun tidak berbeda nyata (Tabel 5)

\section{Tabel 5. Berat Volume Tanah}

\begin{tabular}{ccccccc}
\hline \multirow{2}{*}{$\begin{array}{c}\text { Waktu } \\
\text { Pengamatan }\end{array}$} & Takaran & $5 \mathrm{ml} / \mathrm{L}$ & $5 \mathrm{ml} / \mathrm{L}$ & $10 \mathrm{ml} / \mathrm{L}$ & $10 \mathrm{ml} / \mathrm{L}$ & \\
\cline { 3 - 6 } & Biochar & $2 \mathrm{x}$ & $1 \mathrm{x}$ & $2 \mathrm{x}$ & $1 \mathrm{x}$ & Rerata \\
& & seminggu & seminggu & seminggu & seminggu & \\
\hline \multirow{5}{*}{ Awal } & $10 \mathrm{t} / \mathrm{Ha}$ & 2.17 & 2.10 & 1.98 & 2.03 & $2.07 \mathrm{a}$ \\
& $20 \mathrm{t} / \mathrm{Ha}$ & 2.29 & 1.49 & 1.78 & 1.99 & $1.89 \mathrm{a}$ \\
& $30 \mathrm{t} / \mathrm{Ha}$ & 2.27 & 2.09 & 2.35 & 1.96 & $2.17 \mathrm{a}$ \\
\cline { 2 - 6 } & Rerata & $2.24 \mathrm{a}$ & $1.89 \mathrm{a}$ & $2.04 \mathrm{a}$ & $2.00 \mathrm{a}$ & $(-)$ \\
\hline \multirow{4}{*}{ Akhir } & $10 \mathrm{t} / \mathrm{Ha}$ & 1.35 & 3.00 & 2.64 & 2.54 & $2.38 \mathrm{a}$ \\
& $20 \mathrm{t} / \mathrm{Ha}$ & 2.39 & 1.38 & 2.49 & 2.38 & $2.16 \mathrm{a}$ \\
& $30 \mathrm{t} / \mathrm{Ha}$ & 1.86 & 2.39 & 1.45 & 1.96 & $1.92 \mathrm{a}$ \\
\cline { 2 - 6 } & Rerata & $1.87 \mathrm{a}$ & $2.26 \mathrm{a}$ & $2.19 \mathrm{a}$ & $2.29 \mathrm{a}$ & $(-)$ \\
\hline Keterangan: Angka pada baris dan kolom diikuti huruf yang sama menunjukan beda pada
\end{tabular}

Keterangan: Angka pada baris dan kolom diikuti huruf yang sama menunjukan beda pada tingkat nyata ( $\alpha$ ) 0,05menurut uji DMRT, (-) tidak terjadi interaksi antar faktor

\section{Tinggi Tanaman(cm)}

Hasil sidik ragam anova menunjukkan tidak terjadi interaksi antara perlakuan takaran biochar dan frekuensi penyiraman pupuk organik cair terhadap parameter tinggi tanaman. Pada perlakuan takaran biochar 30 t/ha memberikan nilai tinggi tanaman tertinggi dan tidak berbeda nyata dari awal pengamatan hingga akhir pengamatan (7 HST-28 HST). Sedangkan pada perlakuan frekuensi penyiraman $5 \mathrm{ml} / \mathrm{L} 2 \mathrm{x}$ seminggu memberikan nilai tertinggi pada akhir pengamatan meskipun tidak berbeda nyata di setiap waktu pengamatan (Tabel 6)

\section{Tabel 6. Tinggi Tanaman}

\begin{tabular}{|c|c|c|c|c|c|c|}
\hline \multirow[b]{2}{*}{$\begin{array}{c}\text { Waktu } \\
\text { Pengamatan }\end{array}$} & \multirow[b]{2}{*}{$\begin{array}{l}\text { Takaran } \\
\text { Biochar }\end{array}$} & \multicolumn{4}{|c|}{ Frekuensi penyiraman POC } & \multirow[b]{2}{*}{ Rerata } \\
\hline & & $\begin{array}{c}5 \mathrm{ml} / \mathrm{L} \\
2 \mathrm{x} \\
\text { seminggu }\end{array}$ & $\begin{array}{c}5 \mathrm{ml} / \mathrm{L} \\
1 \mathrm{x} \\
\text { seminggu }\end{array}$ & $\begin{array}{c}10 \mathrm{ml} / \mathrm{L} \\
2 \mathrm{x} \\
\text { seminggu }\end{array}$ & $\begin{array}{c}10 \mathrm{ml} / \mathrm{L} \\
1 \mathrm{x} \\
\text { seminggu }\end{array}$ & \\
\hline \multirow{4}{*}{7 HST } & $10 \mathrm{t} / \mathrm{Ha}$ & 6.50 & 6.33 & 6.00 & 6.17 & $6.25 \mathrm{a}$ \\
\hline & $20 \mathrm{t} / \mathrm{Ha}$ & 6.00 & 6.22 & 6.33 & 6.83 & $6.35 \mathrm{a}$ \\
\hline & $30 \mathrm{t} / \mathrm{Ha}$ & 6.22 & 6.39 & 6.00 & 6.50 & $6.28 \mathrm{a}$ \\
\hline & Rerata & $6.24 a$ & $6.32 \mathrm{a}$ & $6.11 \mathrm{a}$ & $6.50 \mathrm{a}$ & $(-)$ \\
\hline \multirow{4}{*}{$14 \mathrm{HST}$} & $10 \mathrm{t} / \mathrm{Ha}$ & 10.17 & 11.50 & 11.78 & 11.33 & $11.19 \mathrm{a}$ \\
\hline & $20 \mathrm{t} / \mathrm{Ha}$ & 12.00 & 11.89 & 9.61 & 10.56 & $11.01 \mathrm{a}$ \\
\hline & $30 \mathrm{t} / \mathrm{Ha}$ & 13.89 & 12.17 & 10.50 & 11.67 & $12.06 \mathrm{a}$ \\
\hline & Rerata & $12.02 \mathrm{a}$ & $11.85 \mathrm{a}$ & $10.63 \mathrm{a}$ & $11.19 \mathrm{a}$ & $(-)$ \\
\hline \multirow{4}{*}{$21 \mathrm{HST}$} & $10 \mathrm{t} / \mathrm{Ha}$ & 15.22 & 17.17 & 18.44 & 15.22 & $16.51 \mathrm{a}$ \\
\hline & $20 \mathrm{t} / \mathrm{Ha}$ & 17.67 & 18.00 & 13.33 & 14.33 & $15.83 \mathrm{a}$ \\
\hline & $30 \mathrm{t} / \mathrm{Ha}$ & 19.56 & 16.89 & 13.56 & 17.28 & $16.82 \mathrm{a}$ \\
\hline & Rerata & $17.48 \mathrm{a}$ & $17.35 \mathrm{a}$ & $15.11 \mathrm{a}$ & $15.61 \mathrm{a}$ & $(-)$ \\
\hline \multirow{4}{*}{$28 \mathrm{HST}$} & $10 \mathrm{t} / \mathrm{Ha}$ & 20.83 & 19.28 & 23.33 & 20.22 & $20.92 a$ \\
\hline & $20 \mathrm{t} / \mathrm{Ha}$ & 20.33 & 21.83 & 19.33 & 17.33 & $19.71 \mathrm{a}$ \\
\hline & $30 \mathrm{t} / \mathrm{Ha}$ & 24.00 & 22.78 & 18.33 & 21.28 & $21.60 \mathrm{a}$ \\
\hline & Rerata & $21.72 \mathrm{a}$ & $21.30 \mathrm{a}$ & $20.33 a$ & $19.61 \mathrm{a}$ & $(-)$ \\
\hline
\end{tabular}

Keterangan: Angka pada baris dan kolom diikuti huruf yang sama menunjukan beda pada tingkat nyata ( $\alpha$ ) 0,05menurut uji DMRT, (-) tidak terjadi interaksi antar faktor 


\section{Jumlah Daun (helai)}

Hasil sidik ragam anova menunjukkan tidak terjadi interaksi antara perlakuan takaran biochar dan frekuensi penyiraman pupuk organik cair terhadap parameter jumlah daun. Pada perlakuan takaran biochar $30 \mathrm{t} / \mathrm{ha}$ memberikan nilai jumlah daun terbanyak dan tidak berbeda nyata dari awal pengamatan hingga akhir pengamatan (7 HST-28 HST). Sedangkan pada perlakuan frekuensi penyiraman $5 \mathrm{ml} / \mathrm{L} 2 \mathrm{x}$ seminggu memberikan nilai jumlah daun terbanyak pada akhir pengamatan meskipun tidak berbeda nyata di setiap waktu pengamatan (Tabel 7)

Tabel 7. Jumlah Daun

\begin{tabular}{|c|c|c|c|c|c|c|}
\hline \multirow[b]{2}{*}{$\begin{array}{c}\text { Waktu } \\
\text { Pengamatan }\end{array}$} & \multirow[b]{2}{*}{$\begin{array}{l}\text { Takaran } \\
\text { Biochar }\end{array}$} & \multicolumn{4}{|c|}{ Frekuensi penyiraman POC } & \multirow[b]{2}{*}{ Rerata } \\
\hline & & $\begin{array}{c}5 \mathrm{ml} / \mathrm{L} \\
2 \mathrm{x} \\
\text { seminggu }\end{array}$ & $\begin{array}{c}5 \mathrm{ml} / \mathrm{L} \\
1 \mathrm{x} \\
\text { seminggu }\end{array}$ & $\begin{array}{c}10 \mathrm{ml} / \mathrm{L} \\
2 \mathrm{x} \\
\text { seminggu }\end{array}$ & $\begin{array}{c}10 \mathrm{ml} / \mathrm{L} \\
1 \mathrm{x} \\
\text { seminggu }\end{array}$ & \\
\hline \multirow{4}{*}{7 HST } & $10 \mathrm{t} / \mathrm{Ha}$ & 2.33 & 2.55 & 2.67 & 2.67 & $2.55 \mathrm{a}$ \\
\hline & $20 \mathrm{t} / \mathrm{Ha}$ & 2.78 & 3.00 & 2.56 & 2.56 & $2.72 \mathrm{a}$ \\
\hline & $30 \mathrm{t} / \mathrm{Ha}$ & 2.78 & 2.67 & 2.22 & 2.67 & $2.59 \mathrm{a}$ \\
\hline & Rerata & $2.63 \mathrm{a}$ & $2.74 \mathrm{a}$ & $2.48 \mathrm{a}$ & $2.63 \mathrm{a}$ & $(-)$ \\
\hline \multirow{4}{*}{14 HST } & $10 \mathrm{t} / \mathrm{Ha}$ & 3.00 & 3.78 & 3.78 & 3.44 & $3.50 \mathrm{a}$ \\
\hline & $20 \mathrm{t} / \mathrm{Ha}$ & 3.66 & 4.00 & 2.89 & 3.67 & $3.56 \mathrm{a}$ \\
\hline & $30 \mathrm{t} / \mathrm{Ha}$ & 4.00 & 3.89 & 3.67 & 4.00 & $3.89 \mathrm{a}$ \\
\hline & Rerata & $3.55 \mathrm{a}$ & $3.89 \mathrm{a}$ & $3.44 \mathrm{a}$ & $3.70 \mathrm{a}$ & $(-)$ \\
\hline \multirow{4}{*}{$21 \mathrm{HST}$} & $10 \mathrm{t} / \mathrm{Ha}$ & 5.33 & 5.89 & 7.34 & 6.11 & $6.17 \mathrm{a}$ \\
\hline & $20 \mathrm{t} / \mathrm{Ha}$ & 5.78 & 6.33 & 5.11 & 5.67 & $5.72 \mathrm{a}$ \\
\hline & $30 \mathrm{t} / \mathrm{Ha}$ & 6.67 & 6.22 & 5.22 & 6.11 & $6.06 \mathrm{a}$ \\
\hline & Rerata & $5.93 \mathrm{a}$ & $6.15 \mathrm{a}$ & $5.89 \mathrm{a}$ & $5.96 \mathrm{a}$ & $(-)$ \\
\hline \multirow{4}{*}{$28 \mathrm{HST}$} & $10 \mathrm{t} / \mathrm{Ha}$ & 10.00 & 9.78 & 12.00 & 10.34 & $10.53 \mathrm{a}$ \\
\hline & $20 \mathrm{t} / \mathrm{Ha}$ & 11.00 & 11.22 & 9.22 & 9.89 & $10.33 \mathrm{a}$ \\
\hline & $30 \mathrm{t} / \mathrm{Ha}$ & 11.67 & 10.89 & 10.67 & 11.67 & $11.22 \mathrm{a}$ \\
\hline & Rerata & $10.89 a$ & $10.63 \mathrm{a}$ & $10.63 \mathrm{a}$ & $10.63 \mathrm{a}$ & $(-)$ \\
\hline
\end{tabular}

Keterangan: Angka pada baris dan kolom diikuti huruf yang sama menunjukan beda pada tingkat nyata ( $\alpha$ ) 0,05 menurut uji DMRT, (-) tidak terjadi interaksi antar faktor

\section{Luas Daun}

Luas daun menggambarkan proses fotosintesis yang berlangsung. Semakin besar luas daun maka proses fotosintesis yang berlangsung pada daun semakin tinggi sehingga hasil fotosintat yang terbentuk di daunakan semakin banyak (Wibowo et al., 2012).Hasil sidik ragam (anova) menunjukkan tidak terjadi interaksi antara perlakuan takaran biochar dan frekuensi penyiraman pupuk organik cair terhadap parameter luas daun. Pada perlakuan takaran biochar $30 \mathrm{t} / \mathrm{ha}$ memberikan nilai luas daun terlebar dan berbeda nyata dengan aras perlakuan lainnya. Sedangkan pada perlakuan frekuensi penyiraman POC (pupuk organik cair) penyiraman $10 \mathrm{ml} / \mathrm{L} 2 \mathrm{x}$ seminggu memberikan nilai luas daun terlebar dibanding aras perlakuan lainnya dan berbeda nyata (Tabel 8)

Tabel 8. Luas Daun

\begin{tabular}{cccccc}
\hline \multirow{2}{*}{$\begin{array}{l}\text { Takaran } \\
\text { Biochar }\end{array}$} & \begin{tabular}{c}
$5 \mathrm{ml} / \mathrm{L}$ \\
\cline { 2 - 5 }
\end{tabular} & $\begin{array}{c}5 \mathrm{ml} / \mathrm{L} \\
\text { 2x seminggu }\end{array}$ & $\begin{array}{c}10 \mathrm{ml} / \mathrm{L} \\
\text { 1x seminggu }\end{array}$ & $\begin{array}{c}10 \mathrm{ml} / \mathrm{L} \\
\text { 2x seminggu }\end{array}$ & Rerata \\
\hline $10 \mathrm{t} / \mathrm{Ha}$ & 107.80 & 265.90 & 253.60 & 129.20 & $189.14 \mathrm{ab}$ \\
$20 \mathrm{t} / \mathrm{Ha}$ & 135.90 & 131.40 & 140.00 & 82.70 & $122.50 \mathrm{~b}$ \\
$30 \mathrm{t} / \mathrm{Ha}$ & 328.50 & 345.70 & 505.30 & 112.90 & $323.10 \mathrm{a}$ \\
\hline Rerata & $190.73 \mathrm{ab}$ & $247.71 \mathrm{ab}$ & $299.61 \mathrm{a}$ & $108.28 \mathrm{~b}$ & $(-)$ \\
\hline
\end{tabular}

Keterangan: Angka pada baris dan kolom diikuti huruf yang sama menunjukan beda pada tingkat nyata ( $\alpha$ ) 0,05menurut uji DMRT, (-) tidak

\section{Panjang Akar (cm)}

Hasil sidik ragam anova menunjukkan tidak terjadi interaksi antara perlakuan takaran biochar dan frekuensi penyiraman pupuk organik cair terhadap parameter panjang akar. Pada perlakuan takaran biochar 30 t/ha memberikan nilai panjang akar terpanjang meskipun tidak berbeda nyata dengan aras perlakuan lainnya. Sedangkan pada perlakuan frekuensi penyiraman POC (pupuk organik cair) penyiraman $10 \mathrm{ml} / \mathrm{L} 2 \mathrm{x}$ seminggu memberikan nilai panjang akar terpanjang dibanding aras perlakuan lainnya meskipun tidak berbeda nyata (Tabel 9).

Tabel 9. Panjang Akar

\begin{tabular}{cccccc}
\hline \multirow{2}{*}{$\begin{array}{c}\text { Takaran } \\
\text { Biochar }\end{array}$} & $\begin{array}{c}5 \mathrm{ml} / \mathrm{L} \\
\text { 2x seminggu }\end{array}$ & $\begin{array}{c}5 \mathrm{ml} / \mathrm{L} \\
\text { 1x seminggu }\end{array}$ & $\begin{array}{c}10 \mathrm{ml} / \mathrm{L} \\
\text { 2x seminggu }\end{array}$ & $\begin{array}{c}10 \mathrm{ml} / \mathrm{L} \\
1 \times \text { seminggu }\end{array}$ & \\
\hline $10 \mathrm{t} / \mathrm{Ha}$ & 10.01 & 8.73 & 10.81 & 9.39 & $9.74 \mathrm{a}$ \\
$20 \mathrm{t} / \mathrm{Ha}$ & 10.23 & 12.14 & 10.33 & 9.27 & $10.49 \mathrm{a}$ \\
$30 \mathrm{t} / \mathrm{Ha}$ & 12.08 & 10.50 & 11.94 & 10.97 & $11.37 \mathrm{a}$ \\
\hline Rerata & 10.77 & $10.46 \mathrm{a}$ & $11.03 \mathrm{a}$ & $9.87 \mathrm{a}$ & $(-)$ \\
\hline
\end{tabular}

Keterangan: Angka pada baris dan kolom diikuti huruf yang sama menunjukan beda pada tingkat nyata ( $\alpha$ ) 0,05 menurut uji DMRT, (-) tidak terjadi interaksi antar faktor

\section{Berat Segar Total (gram)}

Hasil sidik ragam anova menunjukkan tidak terjadi interaksi antara perlakuan takaran biochar dan frekuensi penyiraman pupuk organik cair terhadap parameter berat segar total. Pada perlakuan takaran biochar $30 \mathrm{t} / \mathrm{ha}$ memberikan nilai berat segar total terberat meskipun tidak berbeda nyata dengan aras perlakuan lainnya. Sedangkan pada perlakuan frekuensi penyiraman POC (pupuk organik cair) penyiraman $5 \mathrm{ml} / \mathrm{L} 1 \mathrm{x}$ seminggu memberikan nilai berat segar total terberat dibanding aras perlakuan lainnya meskipun tidak berbeda nyata (Tabel 10)

\section{Tabel 10. Berat Segar Total}

\begin{tabular}{lccccc}
\hline \multirow{2}{*}{$\begin{array}{c}\text { Takaran } \\
\text { Biochar }\end{array}$} & $5 \mathrm{ml} / \mathrm{L}$ & $5 \mathrm{ml} / \mathrm{L}$ & $10 \mathrm{ml} / \mathrm{L}$ & $10 \mathrm{ml} / \mathrm{L}$ & \multirow{2}{*}{ Rerata } \\
& $\begin{array}{c}\text { 2x seminggu } \\
\text { 1x seminggu }\end{array}$ & $\begin{array}{c}\text { 2x seminggu } \\
1 \times \text { s seminggu }\end{array}$ \\
\hline $10 \mathrm{t} / \mathrm{Ha}$ & 47.22 & 80.43 & 112.48 & 64.82 & $76.24 \mathrm{a}$ \\
$20 \mathrm{t} / \mathrm{Ha}$ & 69.51 & 93.7 & 41.09 & 36.17 & $60.12 \mathrm{a}$ \\
$30 \mathrm{t} / \mathrm{Ha}$ & 105.74 & 72.7 & 44.62 & 100.85 & $80.98 \mathrm{a}$ \\
\hline Rerata & $74.15 \mathrm{a}$ & $82.28 \mathrm{a}$ & $66.06 \mathrm{a}$ & $67.28 \mathrm{a}$ & $(-)$ \\
\hline Keterangan: Angka pada baris dan kolom diikuti huruf yang sama menunjukan beda pada
\end{tabular}

tingkat nyata ( $\alpha$ ) 0,05 menurut uji DMRT, (-) tidak terjadi interaksi antar faktor

\section{Berat Segar Ekonomi (gram)}

Hasil sidik ragam anova menunjukkan tidak terjadi interaksi antara perlakuan takaran biochar dan frekuensi penyiraman pupuk organik cair terhadap parameter berat segar ekonomi. Pada perlakuan takaran biochar 30 t/ha memberikan nilai berat segar ekonomi terberat meskipun tidak berbeda nyata dengan aras perlakuan lainnya. Sedangkan pada perlakuan frekuensi penyiraman POC (pupuk organik cair) penyiraman $5 \mathrm{ml} / \mathrm{L} 1 \mathrm{x}$ seminggu memberikan nilai berat segar ekonomi terberat dibanding aras perlakuan lainnya meskipun tidak berbeda nyata (Tabel 11)

\section{Tabel 11. Berat Segar Ekonomi}

\begin{tabular}{cccccc}
\hline \multirow{2}{*}{$\begin{array}{c}\text { Takaran } \\
\text { Biochar }\end{array}$} & \begin{tabular}{c}
$5 \mathrm{ml} / \mathrm{L}$ \\
\cline { 2 - 5 }
\end{tabular} & $\begin{array}{c}5 \mathrm{ml} / \mathrm{L} \\
\text { 2x seminggu }\end{array}$ & $\begin{array}{c}10 \mathrm{ml} / \mathrm{L} \\
\text { 1x seminggu }\end{array}$ & $\begin{array}{c}10 \mathrm{ml} / \mathrm{L} \\
\text { 2x seminggu }\end{array}$ & Rerata \\
\hline $10 \mathrm{t} / \mathrm{Ha}$ & 44.21 & 75.4 & 105.5 & 59.11 & $71.06 \mathrm{a}$ \\
$20 \mathrm{t} / \mathrm{Ha}$ & 61.7 & 85.64 & 38.88 & 33.32 & $54.89 \mathrm{a}$ \\
$30 \mathrm{t} / \mathrm{Ha}$ & 98.71 & 70.5 & 40.68 & 92.24 & $75.53 \mathrm{a}$ \\
\hline Rerata & $68.21 \mathrm{a}$ & $77.18 \mathrm{a}$ & $61.69 \mathrm{a}$ & $61.55 \mathrm{a}$ & $(-)$ \\
\hline
\end{tabular}

Keterangan: Angka pada baris dan kolom diikuti huruf yang sama menunjukan beda pada tingkat nyata ( $\alpha$ ) 0,05menurut uji DMRT, (-) tidak terjadi interaksi antar faktor

\section{Berat Segar Non Ekonomi (gram)}

Hasil sidik ragam anova menunjukkan tidak terjadi interaksi antara perlakuan takaran biochar dan frekuensi penyiraman pupuk organik cair terhadap parameter berat segar non ekonomi. Pada perlakuan takaran biochar 30 t/ha memberikan nilai berat segarnon ekonomi terberat meskipun tidak berbeda nyata dengan aras perlakuan lainnya. Sedangkan pada perlakuan frekuensi penyiraman POC (pupuk organik cair) penyiraman $5 \mathrm{ml} / \mathrm{L} 1 \mathrm{x}$ seminggu memberikan nilai berat segarnon ekonomi terberat dibanding aras perlakuan lainnya meskipun tidak berbeda nyata (Tabel 12)

\section{Tabel 12. Berat Segar Non Ekonomi}

\begin{tabular}{cccccc}
\hline \multirow{2}{*}{$\begin{array}{c}\text { Takaran } \\
\text { Biochar }\end{array}$} & $\begin{array}{c}5 \mathrm{ml} / \mathrm{L} \\
\text { 2x seminggu }\end{array}$ & $\begin{array}{c}5 \mathrm{ml} / \mathrm{L} \\
\text { 1x seminggu }\end{array}$ & $\begin{array}{c}10 \mathrm{ml} / \mathrm{L} \\
\text { 2x seminggu }\end{array}$ & $\begin{array}{c}10 \mathrm{ml} / \mathrm{L} \\
\text { 1x seminggu }\end{array}$ & \\
\hline $10 \mathrm{t} / \mathrm{Ha}$ & 3.10 & 5.03 & 6.83 & 6.13 & $5.27 \mathrm{a}$ \\
$20 \mathrm{t} / \mathrm{Ha}$ & 7.85 & 7.57 & 3.35 & 4.73 & $5.88 \mathrm{a}$ \\
$30 \mathrm{t} / \mathrm{Ha}$ & 7.95 & 7.17 & 4.66 & 7.43 & $6.80 \mathrm{a}$ \\
\hline Rerata & $6.30 \mathrm{a}$ & $6.59 \mathrm{a}$ & $4.95 \mathrm{a}$ & $6.09 \mathrm{a}$ & $(-)$ \\
\hline Keterangan: Angka pada baris dan kolom diikuti huruf yang sama menunjukan beda pada
\end{tabular}
tingkat nyata $(\alpha)$ 0,05menurut uji DMRT, (-) tidak terjadi interaksi antar faktor

\section{Indeks Panen (\%)}

Hasil sidik ragam anova menunjukkan tidak terjadi interaksi antara perlakuan takaran biochar dan frekuensi penyiraman pupuk organik cair terhadap parameter indeks panen. Pada perlakuan takaran biochar 30 t/ha memberikan nilai indeks panen tertinggi meskipun tidak berbeda nyata dengan aras perlakuan lainnya. Sedangkan pada perlakuan frekuensi penyiraman POC (pupuk organik cair) penyiraman $5 \mathrm{ml} / \mathrm{L} 1 \mathrm{x}$ seminggu memberikan nilai indeks panen tertinggi dibanding aras perlakuan lainnya meskipun tidak berbeda nyata (Tabel 13).

\section{Tabel 13. Indeks Panen}

\begin{tabular}{|c|c|c|c|c|c|}
\hline \multirow[b]{2}{*}{$\begin{array}{l}\text { Takaran } \\
\text { Biochar }\end{array}$} & \multicolumn{4}{|c|}{ Frekuensi penyiraman POC } & \multirow[b]{2}{*}{ Rerata } \\
\hline & $\begin{array}{c}5 \mathrm{ml} / \mathrm{L} \\
2 \times \text { seminggu }\end{array}$ & $\begin{array}{c}5 \mathrm{ml} / \mathrm{L} \\
1 \times \text { seminggu }\end{array}$ & $\begin{array}{c}10 \mathrm{ml} / \mathrm{L} \\
2 \times \text { seminggu }\end{array}$ & $\begin{array}{c}10 \mathrm{ml} / \mathrm{L} \\
1 \times \text { seminggu }\end{array}$ & \\
\hline $10 \mathrm{t} / \mathrm{Ha}$ & 93.47 & 92.80 & 93.67 & 90.65 & $92.65 a$ \\
\hline $20 \mathrm{t} / \mathrm{Ha}$ & 87.33 & 91.80 & 95.26 & 94.32 & $92.18 \mathrm{a}$ \\
\hline $30 \mathrm{t} / \mathrm{Ha}$ & 93.84 & 96.83 & 88.92 & 91.43 & $92.76 \mathrm{a}$ \\
\hline Rerata & $91.55 \mathrm{a}$ & $93.81 \mathrm{a}$ & $92.62 \mathrm{a}$ & $92.13 \mathrm{a}$ & $(-)$ \\
\hline
\end{tabular}




\subsection{Pembahasan}

Hasil Pertumbuhan tanaman yang baik dapat tercapai apabila unsur hara yang dibutuhkan untuk pertumbuhan dan perkembangan tanaman berada dalam bentuk tersedia seimbang dan dalam konsentrasi yang optimum serta didukung oleh faktor lingkungan (Wibawa, 1998) hasil penelitian berkaitan tentang faktor lingkungan menunjukkan tidak terjadi interaksi antara perlakuan takaran biochar dan frekuensi penyiraman POC. Pada perlakuan takaran biochar 30 tha memberikan nilai terbaik pada parameter suhu tanah, derajat keasaman tanah, daya hantar listrik, dan berat volume tanah namun pada parameter kadar lengas tanah perlakuan takaran biochar $10 \mathrm{t} / \mathrm{ha}$ memberikan nilai tertinggi. Menurut Atkinson et al. (2010), penggunaan biochar dapat memperbaiki struktur tanah, tekstur, porositas, distribusi ukuranpartikel dan densitasnya. Sedangkan pada perlakuan frekuensi penyiraman POC perlakuan $5 \mathrm{ml} / \mathrm{L}$ dan 10 $\mathrm{ml} / \mathrm{L}$ baik seminggu sekali maupun $2 \mathrm{x}$ seminggu memberikan nilai tertinggi terhadap parameter lingkungan hal ini dikarenakan, pemberian pupuk organik mampu memperbaiki struktur tanah yang berguna dalam proses penguraian bahan organik menjadi bahan yang tersedia bagi tanaman (Syukur, 2016). Tanaman yang sedang tumbuh, terlihat dengan adanya pembentukan organorgan baru, misalnya daun semakin banyak, tinggi tanaman semakin tinggi dan menuju keukuran yang lebih besar.

Berkaitan tentang pertumbuhan hasil analisis sidik ragam anova menunjukkan tidak terjadi interaksi antara perlakuan takaran biochar dan frekuensi penyiraman POC. Pada parameter tinggi tanaman dan jumlah daun perlakuan takaran biochar $30 \mathrm{t} / \mathrm{ha}$ dan frekuensi penyiraman POC $5 \mathrm{ml} / \mathrm{L} 2 \mathrm{x}$ seminggu memberikan nilai tertinggi. Menurut Kemas (2002), bahwa semua unsur hara mempunyai efek yang sama-sama merugikan pertumbuhan apabila kurang atau tidak tersedia bagi tanaman. Dan sebaliknya sesuai Dwidjoseputro (1991) bahwa tanaman akan tumbuh subur dan memberikan hasil yang baik jika unsur hara yang dibutuhkannya tersedia dalam jumlah cukup dan seimbang.Hasil sidik ragam (Anova) menunjukkan tidak terjadi interaksi antara perlakuan takaran biochar dan frekuensi penyiraman POC. Bahwa bila pengaruh interaksi berbeda tidak nyata, maka disimpulkan bahwa diantara faktor-faktor perlakuan tersebut bertindak bebas satu(Steel et al, 1991) Pada perlakuan takaran biochar $30 \mathrm{t} / \mathrm{Ha}$ memberikan nilai tertinggi terhadap parameter panjang akar, berat segar total, berat segar ekonomi, berat segar non ekonomi, indeks panen dan luas daun. Hasil penelitian Widowati (2010), membuktikan bahwa melakukan pemupukan dan diberikan biochar dalam tanah dapat meningkatkan total panjang akar tanaman selain itu biochar lebih efektif menahan unsur hara untuk ketersediaannya bagi tanaman dibandingkan bahan organik lain. Sedangkan pada perlakuan frekuensi penyiraman POC perlakuan $5 \mathrm{ml} / \mathrm{L} 1 \mathrm{x}$ seminggu dan $10 \mathrm{ml} / \mathrm{L} 2 \mathrm{x}$ seminggu yang mampu memberikan nilai tertinggi.

\section{Simpulan}

Hasil penelitian menunjukkan tidak terjadi interaksi serta bedanyata antara perlakuan takaran biochar dan frekuensi penyiraman POC terhadap pertumbuhan dan hasil tanaman sawi (Brassica rappa L.). Namun terjadi beda nyata pada parameter luas daun.Padaperlakuan takaran biochar $30 \mathrm{t} / \mathrm{ha}$ dan frekuensi penyiraman POC $5 \mathrm{ml} / \mathrm{L}$ mampu meningkatkan pertumbuhan serta hasil tanaman sawi (Brassica rappa L.) hal ini di tunjukkan dengan nilai tertinggi yang diberikan baik pada parameter lingkungan, pertumbuhan serta hasil

\section{Pustaka}

Anas, I., D. Utami, T. Yuliawati, T. Muluk 2003. Lobak (Raphinus spinosum) dan bayam (Amaranthus spp.) sebagai pengganti tanaman Cress (Lepidum sativum) dalam pengujian tingkat kematangan kompos. J. Penelitian Pertanian. 22 (1) : 34-40.

Atkinson C. J., Jean D.F., and Niel A.H., 2010. Potential mechanisms for achieving agricultural benefits from biochar application to temperate soils: areview. Journal Plant and Soil, 337, 1-18.

Badan Pusat Statistikdan Direktorat Jenderal Hortikultura. 2020. Statistik Produksi Hortikultura Tahun 2019. Badan Pusat Statistik dan Direktorat Jenderal Hortikultura, Kementrian Pertanian.

BMKG. 2017. Buletin Pemantauan Ketahanan Pangan Indonesia. Jakarta: BMKG.

Balitklimat. 2003. Atlas Sumberdaya Iklim/Agroklimat untuk Pertanian. Balai Penelitian Agroklimat dan Hidrologi, Bogor.

Dwidjoseputro, D. 1991. Pengantar Fisiologi Tumbuhan. Gramedia, Jakarta.

Gani. 2009. Potensi arang hayati sebagai komponen teknologi perbaikan produktivitas lahan pertanian. Penelitian Pertanian Tanaman Pangan, Iptek Tanaman Pangan (ISSN 1907-4263) Vol.4 No.1 Juli 2009.

Glaser, B., Lehmann, J. and Zech, W. 2002. Ameliorating Physical and Chemical Properties of Highly Weathered Soils in The Tropics with Charcoals A review. Boil and Fertility of Soils (35): p. 219-230.

Gomez, K. A. dan Gomez, A. A. 1995. Prosedur Statistik Untuk Penelitian Pertanian. Edisi ke 2. UI Press: Jakarta.

Hadisuwito, S. 2007. Membuat Pupuk Kompos Cair. PT Agromedia Pustaka. Jakarta

Mulyani, A. dan M. Sarwani. 2013. Karakteristik dan potensi lahan suboptimal untuk pengembangan pertanian di Indonesia. Jurnal Sumberdaya Lahan 2: 47-56.
Jusuf, L. 2006. Potensi Daun Gamal Sebagai Bahan Pupuk Organik Cair Melalui Perlakuan Fermentasi. Gowa: Sekolah Tinggi Penyuluhan Pertanian (STPP). Jurnal Agrisistem, Juni 2006, Vol 2 No. 1 ISSN 1858-4330.

Kemas A. H. (2002). Dasar-Dasar Ilmu Tanah .PT. Raja Grafindo Persada. Jakarta.

Musnamar, E.I. 2003. Pupuk Organik: Cair dan Padat, Pembuatan, Aplikasi. PS: Jakarta.

Parman, Sarjana. 2007. Pengaruh Pemberian Pupuk Organik Cair terhadap Tertumbuhan dan Produksi Kentang (Solanum tuberosum L.). Buletin Anatomi dan Fisiologi Vol. XV, No. 2.

Pardosi, A. H., Irianto dan Mukhsin. 2014. Respons Tanaman Sawi terhadap Pupuk Organik Cair Limbah Sayuran pada Lahan Kering Ultisol. Jambi: Universitas Jambi. Prosiding Seminar Nasional Lahan Suboptimal 2014, Palembang 26-27 September 2014 ISBN: 979. 587-529-9.

Sombroek W, Ruivo, M. L., Fearnside, PM., Glaser, B. and Lehmann, J., 2003. Amazonian dark earths as carbon syores and sink. Online, www.researchgate.net/ Amazonian_Dark_Earths, diakses tanggal 20 September 2012

Steel, R.G.D dan J. H. Torrie. 1991. Prinsip dan Prosedur Statistika Suatu Pendekatan Biometrik. Gramedia Pustaka Utama, Jakarta.

Syukur, M. 2016. 8 Kiat Sukses Panen Cabai Sepanjam Musim. Agromedia. Jakarta.

Tania, N., Astina, \& Budi, S. (2012). Pengaruh pemberian pupuk hayati terhadap pertumbuhan dan hasil jagung semi pada tanah podsolik merah kuning. Jurnal Sains Mahasiswa Pertanian, 1(1), 10-15. Untung, O. (2000). Hidroponik sayuran sistem NFT (Nutrient Film Tecnique). Jakarta:Penebar Swadaya.

Wibowo. A., Purwanti, Setyastuti, R, Rabaniyah. 2012. Pertumbuhan dan Hasil Benih Kedelai Hitam (Glycine max (L.) Merr) Malika yang Ditanam Secara Tumpangsari dengan Jagung Manis (Zea mays Kelompok Saccharata). Vegetalika 1(4): 1-10.

Widowati. 2010. Produksi dan Aplikasi Biochar / Arang dalam Mempengaruhi Tanah dan Tanaman. Disertasi.Fakultas Pertanian Universitas Brawijaya. Malang.

Wibawa, G. 1998. Dasar-Dasar Fisiologi Tanaman. Suryandra Utama. Semarang. 